\title{
Pengelolaan Tanaman Terpadu (PTT) Padi Ramah Lingkungan Terhadap Hasil Padi dan Emisi Gas Rumah Kaca di lahan Sawah Irigasi
}

\author{
Agus Supriyo ${ }^{1}$, Y. Hindarwati ${ }^{1}$, dan R. Nurlaily ${ }^{1}$ \\ 1Balai Pengkajian Teknologi Pertanian Jawa Tengah, e-mail: agssupriyo@yahoo.com
}

\begin{abstract}
ABSTRAK
Budidaya padi merupakan salah satu sumber potensial penyumbang gas rumah kaca seperti gas methan $\left(\mathrm{CH}_{4}\right)$, yang menyumbang sekitar $11 \%$ berupa emisi gas $\mathrm{CH}_{4}$ di dalam atmosfer. Implementasi pengelolaan tanaman terpadu (PTT) padi sawah ramah lingkungan diharapkan mampu menekan emisi gas methan. Pengkajian telah dilaksanakan dengan tujuan untuk mendapatkan paket teknologi PTT padi Ramah Lingkungan yang meningkatkan hasil padi dan menurunkan emisi gas methan pada lahan sawah irigasi. Pengkajian di lahan petani ("Onfarm research") telah dilaksanakan pada daerah penghasil varietas Rojolele yaitu di Desa Gempol, Kab. Klaten dari bulan Maret sampai bulan September 2016 seluas 1,8 ha yang melibatkan sembilan petani binaan, setiap petani seluas 0,20 hektar. Rancangan Acak Kelompok digunakan dengan delapan ulangan. Dua jenis PTT Padi Ramah Lingkungan dan Pengelolaan Tanaman Terpadu Padi eksisting.Pertama, PTT Padi Ramah Lingkungan (PTTRL) teridiri atas dua sumber pupuk organik yaitu pupuk kandang (PTTPukan) dan petroganik (PTTPetro) . Kedua, PTT eksisting yang dominan ( $\mathrm{PTT}_{\text {Exist }}$ ). Data yang dikumpulkan meliputi tinggi tanaman, jumlah anakan, komponen hasil dan hasil padi. Pengamatan emisi (gas $\mathrm{CH}_{4}$ dan gas $\mathrm{N}_{2} \mathrm{O}$ ) dengan menggunakan "sungkup" pada umur 42, 63, 105 dan 112 Hari setelah tanam (Hst). Pengukuran emisi rumah kaca dilaksanakan di Kantor Balingtan Pati. Analisis data menggunakan Uji beda Duncan pada taraf 0,05. Hasil penelitan menunjukkan bahwa (1) Penerapan (PTTPetro) memberikan hasil yang tertinggi $(5,219 \mathrm{t}$ GKP/ha) meningkatkan hasil sebesar $30 \%$ di atas kontrol ((3.620 t GKP/ha), dan menurunkan emisi gas $\mathrm{CH}_{4}$ sebesar 13,6\% di bawah kontrol (emisi:76,05kg $\mathrm{CH}_{4} / \mathrm{ha} /$ musim).
\end{abstract}

Kata kunci: PTT , Padi, Emisi gas metana (CH4), Sawah irigasi

\begin{abstract}
Rice cultivation to produce of highest methan gases i.e $2.57 \mathrm{Tg}$ per years. The implementation of rice integrated plant management (IPM) to increase of productivuty and able to supress of greenhouse emission (GHGs). The Goals of this experiment was to find out of environmental friendly. On farm research was conducted in central development of Rojolele variety i.e Gempol, Karanganom subdistrict, Klaten district since March-September 2016 about 1.60 hectares. Randomized Block Designs used with eight replicated (eight farmers, each farmers about 0,20 ha). Two kinds of Rice IPM, First, Rice IPM enviromental friendly (IPMR-EF) with eight farmers as replicated. Technology componen of (IPMR-EF) consisted of two source of organic fertilizer i.e Farm yard manure (IPMFYM) and petroganik (IPMPetro), Third treatment (IPMR-ext) were rice farmer management dominant, consisted of (a) Rojolele variety, seedling age 25 days (b), "Tegel transplanting system" (c), farmers dominant fertilizer dosages (d), pestidicide calender system.Parameters were collected such as plant growth, yield component and yield. Observers of greenhouse emission such as $\mathrm{CH}_{4}$ and $\mathrm{N}_{2} \mathrm{O}$ used "Box Chamber" at 42; 63; 105; and 112 days after transplanting. Emisson methan and $\mathrm{N}_{2} \mathrm{O}$ were conducted in in Indonesian Agricultural Environment Research Institute (IAERI) in Pati. Input-output" data farming system among (IPMR-EFTg and IPMR-Effym) compared to control (IPMR-ext). Technical data were analized by variant analysis continued by DMRT 05 . Research resulted that (1) IPMR-FYM to give highest yield $(5,219 \mathrm{t}$ $\mathrm{Gkg} / \mathrm{ha}$ ) to increase $30 \%$ over control (3.620 t Gkg/ha), but to decrease methan gas emission 13,6 \% under control/IPMExist (gas $\mathrm{CH}_{4}$ emission : 76,05 $\mathrm{kg} \mathrm{CH}_{4} / \mathrm{ha}$ /seasons).
\end{abstract}

Keywords: IPM, , Rice, Glasshouse emission, Irrigated land

Citation: Supriyo, A., Hindarwati, Y.,dan Nurlaily, R.(2020). Pengelolaan Tanaman Terpadu (PTT) Padi Ramah Lingkungan Terhadap Hasil Padi dan Emisi Gas Rumah Kaca di lahan Sawah Irigasi. Jurnal Ilmu Lingkungan, 18(1),15-22, doi:10.14710/jil.18.1.15-22

\section{Pendahuluan}

Ketahanan pangan mulai dari tingkat rumah tangga tani hingga nasional diperlukan dalam menjaga stabilitas produksi dan kebutuhan bahan pangan. Untuk itu strategi peningkatan produksi dan produktivitas tanaman padi telah dikembangkan melalui pendekatan Pengelolaan Tanaman Terpadu (PTT) Padi.

Hasil aplikasi PTT di lahan sawah irigasi pada tingkat penelitian dan demontrasi pada luasan terbatas (1-5 ha) dapat meningkatkan rerata hasil 27\% (Badan Litbang Pertanian, 2007). Namun Sarlan 
(2011) melaporkan bahwa evaluasi antara penerapan PTT padi dengan SRI (System Rice Intecification) pada empat lokasi selama dua musim tanam menunjukkan bahwa produktivitas (hasil) padi dan kualitas beras (rendemen, butir pecah dan butir mengapur) penerapan PTT padi lebih tinggi dibandingkan dengan penerapan SRI.

Hasil kegiatan pendampingan Sekolah Lapang (SL) - PTT di Jawa Tengah pada tahun 2010, menunjukkan bahwa rerata hasil VUB padi kegiatan Demplot lebih tinggi dari pada hasil padi di hamparan non SL-PTT dengan kenaikan rerata 1,76 t/ha dibanding lokasi non SL-PTT. Penerapan komponen PTT sistem tanam jajar legowo (2:1) di beberapa lokasi demfarm antara 0,32 - 2,30 t GKP/ha atau meningkat rerata 13,14 \% dibandingkan tanam sistem tegel (Kushartanti et al., 2010).

Sektor pertanian disinyalir sebagai salah satu sumber emisi gas rumah kaca, terutama gas metan. Luas sawah di Indonesia yang lebih dari 8,9 juta hektar diduga memberi kontribusi sekitar 1\% dari total global metana (Bappenas, 2010). Jika total metana diduga berbanding lurus dengan total produksi padi maka setiap usaha peningkatan produksi padi harus dibayar dengan kerusakan lingkungan berupa meningkatnya emisi metan. Kontribusi metana pada pemanasan global berlipat ganda dibandingkan gas rumah kaca lainnya. Metana mempunyai kapasitas pemanasan global 21 kali lebih besar dari karbondioksida (Setyanto, P, 2006). Bila penerapan PTT ternyata dapat menekan emisi GRK, maka sistem ini menjadi ideal karena selain dapat menghemat penggunaan input produksi, menaikkan hasil dan pendapatan petani, juga dapat mengurangi emisi GRK sehingga sistem pertanian menjadi lebih lestari dan ramah lingkungan (Soemarno $d k k$., 2000).

Menghadapi perubahan iklim global, Pemerintah Indonesia telah berkomitmen untuk menurunkan emisi GRK secara nasional hingga 29\% (un conditional) dan dalam kondisional penurunan emisi GRK sebesar $41 \%$ dibandingkan dengan skenario bussinus as usual dibandingkan pada Tahun 2030 (Kementrian LHK, 2017).

Berdasarkan Rencana Aksi Nasional dalam menghadapi perubahan iklim yang diterbitkan oleh Kementerian Negara Lingkungan Hidup (2007), berbagai sektor kehidupan di Indonesia, termasuk sektor pertanian perlu melakukan kegiatan mitigasi dan adaptasi terhadap perubahan iklim. Memperhatikan hal tersebut, produksi padi di masa yang akan datang bukan hanya ditujukan untuk stabilitas ketahanan pangan, tetapi juga untuk mitigasi emisi GRK dan stabilitas ketahanan energi.

Jawa Tengah mempunyai beberapa varietas padi lokal yang telah dilepas sebagai varietas unggul nasional atau terdaftar pada Pusat Perlindungan Varietas Tanaman (PVT) Kementerian Pertanian.
Varietas tersebut menjadi icon Propinsi Jawa Tengah, seperti Rojolele, Pepe dan Mentik Wangi yang mulai menyebar di berbagai wilayah Jawa Tengah disamping wilayah asalnya. Petani umumnya berusahatani varietas lokal ini dengan sistem budidaya konvensional, belum banyak yang menggunakan sistem pendekatan PTT.

Tujuan pengkajian adalah untuk mendapatkan rakitan komponen teknologi PTT padi ramah lingkungan dan menurunkan emisi gas rumah kaca (GRK) sesuai dengan kondisi biofisik dan lingkungan spesifik pada lahan sawah irigasi.

\section{Bahan dan Metode \\ 2.1. Bahan dan alat}

Bahan yang digunakan meliputi padi varietas Rojolele, pupuk kandang (pukan), pupuk Urea, Phonska, SP-36, ZA, agensia nabati (Beuveria bassiana; Metharizium $s p$, Trichoderma $s p$ ) dan gas standard $\mathrm{CH}_{4}, \& \mathrm{~N}_{2} \mathrm{O}$, Regent $5 \mathrm{EC}$ dan larutan garam.

Alat-alat yang digunakan di lapangan meliputi boks penangkap gas yang terbuat dari pleksiglas (Gambar.1), alat injeksi (syringe) polypropilen berukuran $10 \mathrm{ml}$ atau vial $10 \mathrm{ml}$, termometer, $\mathrm{pH}$ meter, bagan warna daun, meteran, timbangan, Kromatografi Gas Shimadzu seri GC-8A untuk analisa gas $\mathrm{CH}_{4}$ dan $\mathrm{GC}-14 \mathrm{~A}$ untuk analisa gas $\mathrm{N}_{2} \mathrm{O}$ dan seperangkat komputer yang digunakan untuk menganalisis data.

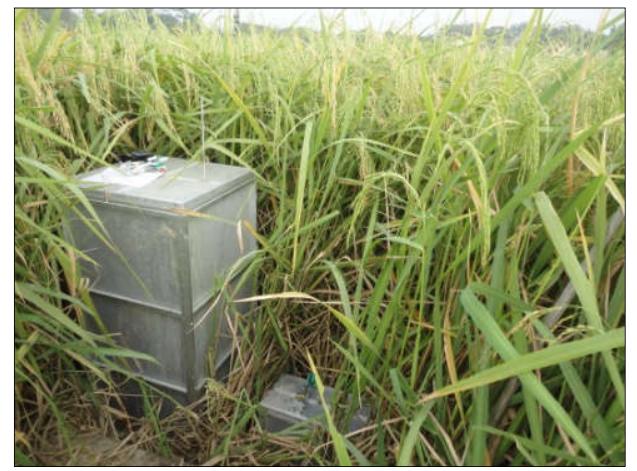

Gambar 1 Boks perangkap gas

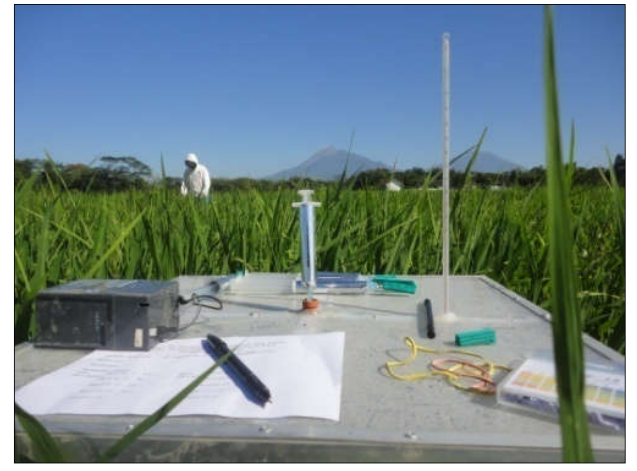

Gambar 2 Alat pengambilan sampel gas 


\subsection{Tempat dan Waktu Penelitian}

Pengkajian penerapan pengelolaan tanaman terpadu padi lokal dilaksanakan pengkajian di lahan petani (on farm research).Di sentra pengembangan varietas lokal identitas Jawa Tengah, yaitu Desa Gempol, Kecamatan Karanganom, Kabupaten Klaten sebagai sentra pengembangan varietas Rojolele mulai bulan Maret - September 2016. Rancangan acak kelompok (RAK) digunakan dengan 8 ulangan (petani) dengan luas petak masing-masing 0,2 ha, total areal 1,6 hektar. Luas setiap petak perlakuan 660 $\mathrm{m}^{2}$. Ada tiga perlakuan yaitu (1) Rakitan komponen
PTT Padi ramah lingkungan (PTT ${ }_{\mathrm{RL}}$ ) yang dibedakan hanya penggunaan sumber pupuk organik yaitu 0,5 ton Petroganik/ha (PTTPetro) dan kedua (2) Kedua sumber pupuk organik berupa 2 ton Pukan/ha

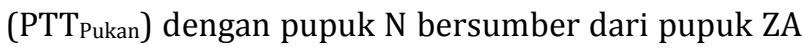
(3). Pengelolaan tanaman terpadu yang dominan dan sesuai kebiasaan petani (PTT existing), sedangkan sumber pupuk nitrogen pada $\mathrm{PTT}_{\text {existing berupa urea. }}$ Rakitan komponen teknologi PTT Padi ramah lingkungan dan PTT Padi eksisting secara rinci disajikan pada Tabel 1.

Tabel 1. Komponen teknologi PTT Padi lokal potensial ramah lingkungan (PTRL) dibanding dengan komponen PTT Padi eksisting Tahun 2016

\begin{tabular}{|c|c|c|}
\hline Perlakuan (Model Pendekatan) & Komponen teknologi & Komponen input produksi \\
\hline \multirow[t]{8}{*}{$\begin{array}{l}\text { PTT Padi lokal ramah lingkungan } \\
\text { (PTT }{ }_{\text {RL }} \text { ) }\end{array}$} & Benih, jumlah, seleksi & $\begin{array}{l}\text { Rojolele, } 25 \mathrm{~kg} / \mathrm{ha} \text {, "seed treatment" Regent } 5 \\
\mathrm{SC} \text {, direndam larutan garam } 3 \% \text {. }\end{array}$ \\
\hline & Pembibitan, umur bibit & $\begin{array}{l}\text { Semai basah di lapangan, ditanam umur } 20 \\
\text { hari, akar dibenamkan vertikal }\end{array}$ \\
\hline & Pemupukan & $\begin{array}{l}0,5 \text { t Petroganik/ha }+\mathrm{N}^{*} \text { berdasar Bagan } \\
\text { Warna Daun }(\mathrm{BWD}) *+\mathrm{P} \text { dan K berdasarkan } \\
\text { Perangkat Uji Tanah Sawah }\left(\mathrm{PTT}_{\text {Petro }}\right) \\
2,0 \text { t Pukan/ha }+\mathrm{N}^{*} \text { berdasar BWD, + P dan K } \\
\text { berdasarkan PUTS (PTT-Pukan) }\end{array}$ \\
\hline & Cara tanam & Jajar legowo tipe $2: 1$ \\
\hline & Jumlah bibit & $1-2$ batang/dapur \\
\hline & Pengendalian Organisme Pengganggu & Pemantauan jumlah telur Penggerek batang \\
\hline & Tanaman (OPT) & $\begin{array}{l}\text { fase persemaian. Pada pertanaman } \\
\text { menggunakan pesetisida hayati (Metarhizium } \\
\text { anisopliae } 5 \mathrm{cc} / \mathrm{l} \text {, Beauveria basisiana). Bila } \\
\text { hasil pemantuan populasi wereng } 5 \text { ekor/rpn } \\
\text { dan } 2 \text { kelompok telur } / \mathrm{m}^{2} \text { dilakukan } \\
\text { pengendalian dengan insektisida efektif } \\
\text { sesuai jazad sasaran. }\end{array}$ \\
\hline & Pengendalian gulma & Mekanis menggunakan gasrok. \\
\hline \multirow[t]{6}{*}{ PTT $_{\text {Exist }}$ (cara petani) } & Benih, seleksi & $\begin{array}{l}\text { Varietas Rojolele, tanpa perlakuan, seleksi } \\
\text { benih dengan garam } 3 \%\end{array}$ \\
\hline & Umur bibit & Semai basah, ditanam umur 25 hari \\
\hline & Pemupukan & $\begin{array}{l}\text { Dosis dominan di petani (150 Urea+200 } \\
\text { Pukan) kg/ha }\end{array}$ \\
\hline & Cara tanam & Jajar legowo tipe $2: 1$ \\
\hline & Pengendalian OPT & $\begin{array}{l}\text { Penggunaan pestisida sesuai kebiasaan } \\
\text { petani }\end{array}$ \\
\hline & Penyiangan & Manual pada umur 21 dan 42 Hst atau Gasrok \\
\hline
\end{tabular}

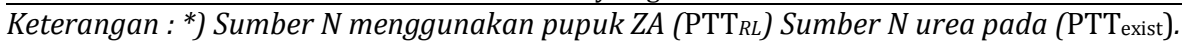

Data yang dikumpulkan :

(a) Data pertumbuhan tanaman, (tinggi tanaman dan jumlah anakan fase vegetatif maksimum dan menjelang panen) komponen hasil (jumlah gabah isi dan berat 1000 biji) pada 10 tanaman contoh/petak, Hasil panen ubinan ( $2 \mathrm{~m} \times 5 \mathrm{~m}$ ) tiga ulangan setiap petak perlakuan dikonversikan ke dalam hektar pada kadar air 14\%. Berat gabah ubinan ditimbang untuk mendapatkan Berat basah ubinan, Kering panen, Kering Giling dan Berat 1000 biji kemudian dikonversikan ke dalam hektar.

(b) Data emisi GRK

Pengukuran emisi GRK meliputi emisi gas metana $\left(\mathrm{CH}_{4}\right)$ dan Dinitrogen oksida $\left(\mathrm{N}_{2} \mathrm{O}\right)$ dengan metode seperti yang dilakukan Isminingsih (2009) dan Ariani et al. (2011) dengan mengambil contoh gas diambil satu hari setelah tanam, selanjutnya pada tiap-tiap fase yaitu fase pertumbuhan vegetatif aktif, fase reproduktif dan fase pemasakan dan dilaksanakan pada pagi hari jam 07.00 WIB. Prosedur pengukuran emisi GRK adalah sebagai berikut:

(b1). Pengambilan contoh gas $\mathrm{CH}_{4}$ dilakukan secara manual menggunakan kotak berukuran $50 \mathrm{~cm}$ x $50 \mathrm{~cm}$ x $100 \mathrm{~cm}$. Emisi GRK diukur secara manual pada setiap petak perlakuan. Sampel diambil dengan menggunakan jarum suntik volume $10 \mathrm{ml}$ dengan interval waktu pengambilan setiap menit ke-5, 10, 15, 20dan 25. Pengambilan sampel $\mathrm{CH}_{4}$ dilakukan setiap 1 minggu sekali.

(b2) Pengambilan contoh gas $\mathrm{N}_{2} \mathrm{O}$ dilakukan secara manual menggunakan kotak berukuran $40 \mathrm{~cm}$ x $20 \mathrm{~cm}$ x $20 \mathrm{~cm}$. Pengambilan contoh $\mathrm{N}_{2} \mathrm{O}$ juga dilakukan setiap 1 minggu sekali. Pengambilan sampel $\mathrm{N}_{2} \mathrm{O}$ menggunakan 
dengan jarum suntik $10 \mathrm{ml}$, dengan interval waktu pengambilan pada menit ke-10, 20, 30, 40 dan 50.

Analisis data : (a) data teknis dilakukan analisis ragam untuk melihat keragaman antar rakitan teknologi yang dikaji, Bilamana ada perbedaan antar rakitan teknologi yang dikaji dilanjutkan dengan UBD pada $\mathrm{P}=0,05$ ), yang akan dilanjutkan dengan analisis korelasi untuk melihat hubungan antara parameter. (b) Analisis data pengukuran emisi GRK: Contoh gas $\mathrm{CH}_{4}$ dan $\mathrm{N}_{2} \mathrm{O}$ dianalisis menggunakan Gas Chromatografi (GC) tipe Varian GHG 240. Hasil analisa contoh gas dapat dihitung menjadi fluks atau emisi GRK dengan menggunakan formulasi (Khalil et al. 1991).

$$
\mathrm{E}=\frac{d c}{d t} \times \frac{\mathrm{Vch}}{\mathrm{Ach}} \times \frac{\mathrm{mW}}{m V} \times \frac{273,2}{(273,2+T)}
$$

\section{Keterangan :}

E : Emisi gas $\mathrm{CH}_{4} / \mathrm{CO}_{2} / \mathrm{N}_{2} \mathrm{O}\left(\mathrm{mg} / \mathrm{m}^{2} /\right.$ hari $)$

$\mathrm{dc} / \mathrm{dt} \quad:$ Perbedaan konsentrasi $\mathrm{CH}_{4} / \mathrm{CO}_{2} / \mathrm{N}_{2} \mathrm{O}$

per waktu (ppm/menit)

Vch : Volume boks $\left(\mathrm{m}^{3}\right)$

Ach : Luas boks $\left(\mathrm{m}^{2}\right)$

$\mathrm{mW} \quad$ : Berat molekul $\mathrm{CH}_{4} / \mathrm{CO}_{2} / \mathrm{N}_{2} \mathrm{O}(\mathrm{g})$

$\mathrm{mV} \quad$ : Volume molekul $\mathrm{CH}_{4} / \mathrm{CO}_{2} / \mathrm{N}_{2} \mathrm{O}(22,41 \mathrm{l})$

$\mathrm{T} \quad$ : Temperatur rata-rata selama

pengambilan contoh gas $\left({ }^{\circ} \mathrm{C}\right)$

Formulasi Estimasi emisi contoh terbatas :

$$
E=\frac{(\text { Flux I + Flux II + Flux III + Flux IV })}{(\mathrm{Ls}-\mathrm{N})} \times(\mathrm{H}-\mathrm{N})
$$

$\begin{array}{ll}\mathrm{LS} & =\text { umur terakhir pengambilan contoh (hst) } \\ \mathrm{N} & =\text { umur bibit (hari) } \\ \mathrm{H} & \text { = Umur panen (hari) }\end{array}$

\section{Hasil dan Pembahasan}

\subsection{Karakteristik kimia tanah}

Karakteristik tanah lokasi pengkajian mempunyai tingkat kemasaman tanah agak masam $(\mathrm{pH}$ tanah $=5,70)$, kandungan C-organik tanah sangat rendah $<1(0,58 \%), \quad \mathrm{N}$-total $=0,10 \%$ tergolong rendah (Tabel 2). Hal ini sesuai dengan fakta bahwa pola tanam tiga kali setahun padi-padipadi, sedangkan status P-tsd, P-total tergolong tinggi (Tabel 2). Ini menunjukkan bahwa pertanian tanaman pangan (padi) secara intensif bahwa aplikasi pupuk $\mathrm{N}$ khususnya masih dibawah rekomendasi Permentan No 6 Tahun 2007, berdasarkan wawancara takaran urea yang digunakan antara 125 - $175 \mathrm{~kg}$ Urea/ha, sedangkan aplikasi pupuk organik jarang dilaksanakan, meskipun beberapa petani menggunakan pupuk organik (sumber pupuk kandang) masih di bawah rekomendasi 500 - $1000 \mathrm{~kg} / \mathrm{ha}$. Jerami padi hasil panen diangkut keluar digunakan untuk makanan ternak. Akibatnya untuk mempertahankan kandungan bahan organik tanah diperlukan penambahan pupuk organik untuk meningkatan kandungan C-organik tanah, karena penambahan unsur hara lain akan terjerap lebih baik, sehingga produktivitas yang diperoleh dapat meningkat.

\begin{tabular}{|c|c|c|c|c|}
\hline Karakteristi kimia tanah & Satuan & Metode & Nilai & Kriteria* \\
\hline $\mathrm{pH}\left(\mathrm{H}_{2} \mathrm{O}\right)$ & - & Elektrometri & 5,70 & Agak masam \\
\hline $\mathrm{pH}(\mathrm{KCl})$ & - & Elektrometri & 4,75 & Agak masam \\
\hline C-organik & $\%$ & Spektrofotometri & 0,58 & Sangat rendah \\
\hline N-Kjeldal & $\%$ & Titimetri & 0,10 & Rendah \\
\hline P-tersedia Olsen & ppm & Spektrofotometri & 22,50 & Tinggi \\
\hline $\mathrm{P}_{2} \mathrm{O}_{5}(\mathrm{HCl} 25 \%)$ & $\mathrm{mg} / 100 \mathrm{~g}$ & Spektrofotometri & 45,50 & Tinggi \\
\hline $\mathrm{K}_{2} \mathrm{O}(\mathrm{HCl} 25 \%)$ & $\mathrm{mg} / 100 \mathrm{~g}$ & Spektrofotometri & 56,30 & Tinggi \\
\hline KTK & $\mathrm{cmol}^{(+)} \mathrm{kg}^{-1}$ & Titimetri & 13,36 & Rendah \\
\hline Ca-dd & $\mathrm{cmol}^{(+)} \mathrm{kg}^{-1}$ & Spektrofotometri & 9,12 & Tinggi \\
\hline Mg-dd & $\mathrm{cmol}^{(+)} \mathrm{kg}^{-1}$ & Spektrofotometri & 2,38 & Tinggi \\
\hline$K-\mathrm{dd}$ & $\mathrm{cmol}^{(+)} \mathrm{kg}^{-1}$ & Spektrofotometri & 0,56 & Sedang \\
\hline Na-dd & $\mathrm{cmol}^{(+)} \mathrm{kg}^{-1}$ & Spektrofotometri & 1,30 & Tinggi \\
\hline
\end{tabular}

Tabel 2. Karakteristik kimia tanah lahan sawah irigasi di Desa Gempol, Kec. Karanganom, Kabupaten Klaten MK , 2016

*) Status unsur hara tanah ditetapkan berdasarkan Pusat Penelitian Tanah, 1986

\subsection{Pertumbuhan tanaman padi}

Perlakuan (PTTPukan) padi varietas Rojolele pada lahan sawah irigasi meningkatkan tinggi tanaman secara nyata (Tabel 3). Peningkatan tinggi tanaman fase vegetatif sebesar 6,7 \% di atas (PTTexist dengan tinggi tanaman : $118 \mathrm{~cm}$. Hal ini diduga bahwa penambahan 2 ton pukan/ha dapat meningkatkan ketersediaan unsur hara di dalam tanah menjadi meningkat, karena bahan organik berperan didalam meningkatkan jerapan kation-kation atau anion-anion di dalam tanah yang diberikan melalui pemupukan. Disamping itu didukung kandungan C-organik tanah sangat rendah penyerapan unsur hara yang diberikan melalui pemupukan lebih efisien. Akibatnya penyerapan unsur hara terutama N, P dan K kedalam tanaman lebih cepat dan pembelahan sel-sel pada jaringan lebih cepat (Machener, 1986). Demikian juga perlakuan pemberian 0,5 t petroganik meningkatkan tinggi tanaman secara nyata dengan peningkatan tinggi tanaman sebesar 5,35 \% di atas kontrol (113 $\mathrm{cm}$ ). Bila dibandingkan dengan pupuk kandang peningkatannya lebih rendah. Hal ini diduga aplikasi pupuk organik dalam bentuk pupuk kandang lebih cepat mengalami dekomposisi dibandingkan dengan petroganik. Disamping itu penerapan PTT padi ramah lingkungan menggunakan komponen pemberian irigasi secara selang satu minggu, hal ini diduga 
meningkatkan efisien penggunaan air dalam fotosintesis sehingga akumulasi biomas yang dicerminkan dengan peningkatan tinggi tanaman. lebih tinggi.

Secara konsisten penerapan (PTT Pukan $_{\text {) }}$ meningkatkan tinggi tanaman menjelang panen secara nyata (Tabel 3). Peningkatan tinggi tanaman fase vegetatif sebesar $14,97 \%$ di atas (PTT ${ }_{\text {exist}}$ ) dengan tinggi tanaman :167 cm. Hal ini diduga bahwa penambahan 2 ton pukan/ha dapat meningkatkan ketersediaan unsur hara di dalam tanah menjadi meningkat, karena bahan organik berperan di dalam meningkatkan jerapan kation-kation atau anion-anion di dalam tanah yang diberikan melalui pemupukan. Disamping itu didukung kandungan C-organik tanah sangat rendah penyerapan usnur hara yang diberikan melalui pemupukan lebih efisien. Akibatnya penyerapan unsur hara terutama N, P dan K ke dalam tanaman lebih cepat dan pembelahan sel-sel pada jaringan lebih cepat (Fauziah, H, 2012). Demikian juga perlakuan PTTPetro meningkatkan tinggi tanaman secara nyata dengan peningkatan tinggi tanaman sebesar $11,37 \%$ di atas kontrol $(167 \mathrm{~cm})$. Bila dibandingkan dengan pupuk kandang peningkatannya lebih rendah. Hal ini diduga aplikasi pupuk organik dalam bentuk pupuk kandang lebih cepat mengalami dekomposisi dibandingkan dengan petroganik. Secara morfologis memang padi varietas Rojolele mempunyai tinggi tanaman hampir $2 \mathrm{~m}$, dan tipe daun terkulai. Nampaknya penerapan PT padi lokal dengan menerapkan beberapa komponen teknologi PTT (benih muda 20 hari, tanam jajar legowo dan pengairan secara berselang dan pengendalian OPT secara pemantauan dengan pestisida nabati) tanggap tinggi tanaman menjelang panen lebih baik dibandingkan dengan PTT existing. $_{\text {. }}$

Perlakuan (PTTPukan) padi ramah lingkungan pada lahan sawah irigasi meningkatkan jumlah anakan/rumpun secara nyata (Tabel 3). Peningkatan jumlah anakan/rumpun pada fase vegetatif sebesar $28,6 \%(18,0-14,0): 14)$ di atas jumlah anakan/rpn pada pengelolaan tanaman cara petani/kontrol (jumlah anakan 14 /rumpun). Hal ini diduga karena penambahan 2 ton pukan/ha dapat meningkatkan ketersediaan unsur hara di dalam tanah dan meningkatkan jerapan kation-kation atau anion-anion di dalam tanah yang diberikan melalui pemupukan. Disamping itu didukung kandungan C-organik tanah sangat rendah penyenyerapan usnur hara yang diberikan melalui pemupukan lebih efisien. Akibatnya penyerapan unsur hara terutama $\mathrm{P}$ dan $\mathrm{K}$ ke dalam tanaman lebih lancar dan pembelahan sel-sel pada jaringan muda lebih cepat (Fauziah, H. 2012). Sedangkan perlakuan PTTPetro meningkatkan jumlah anakan/rumpun hanya sebesar $17,85 \%$ di atas

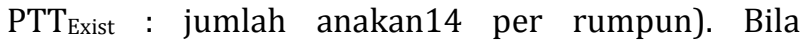
dibandingkan dengan pukan peningkatannya lebih rendah. Hal ini diduga aplikasi pupuk organik dalam bentuk pupuk kandang lebih cepat terdekomposisi dibandingkan dengan petroganik.

Perlakuan PTTPukan padi ramah lingkungan pada lahan sawah irigasi meningkatkan jumlah anakan produktif/rumpun secara nyata (Tabel 6). Peningkatan jumlah anakan produktif/rumpun sebesar 37,5 \% di atas jumlah anakan/rpn PTTExist (jumlah anakan 8/rumpun). Hal ini diduga karena penambahan 2 ton pukan/ha dapat meningkatkan ketersediaan unsur hara di dalam tanah dan meningkatkan jerapan kation-kation atau anion-anion di dalam tanah yang diberikan melalui pemupukan. Disamping itu didukung kandungan C-organik tanah sangat rendah penyerapan usnur hara yang diberikan melalui pemupukan lebih efisien. Akibatnya penyerapan unsur hara terutama $\mathrm{P}$ dan $\mathrm{K}$ ke dalam tanaman lebih lancar dan pembelahan sel-sel pada jaringan muda lebih cepat (Fauziah, H, 2012). Sedangkan perlakuan pemberian $0,5 \mathrm{t}$ petroganik meningkatkan jumlah anakan/rumpun hanya sebesar $25,00 \%$ di atas kontrol ( 8 anakan per rumpun). Bila dibandingkan dengan pupuk kandang peningkatannya lebih rendah. Ini diduga aplikasi pupuk organik dalam bentuk pupuk kandang lebih cepat terdekomposisi dibandingkan dengan petroganik.

Tabel 3. Penerapan PTT Padi ramah lingkungan terhadap tinggi tanaman dan jumlah anakan padi var. Rojolele di Desa Gempol, Kec. Karanganom, Kab. Klaten MK 2016

\begin{tabular}{|c|c|c|c|c|}
\hline Perlakuan & $\begin{array}{l}\text { Tinggi tan stadia } \\
\text { vegetatif }(\mathrm{cm})\end{array}$ & $\begin{array}{c}\text { Tinggi tanaman jelang } \\
\text { panen }(\mathrm{cm})\end{array}$ & $\begin{array}{c}\text { Jml anakan/ } \\
\text { rumpunstadia vegetatif }\end{array}$ & $\begin{array}{l}\text { Jml anakan } \\
\text { produktif/rpnl }\end{array}$ \\
\hline PTTPetr $^{* *}$ & $118,0 \quad b^{*}$ & $186 \mathrm{ab}^{*}$ & $16,5 \mathrm{ab}^{*}$ & $10,0 \mathrm{ab}^{*}$ \\
\hline $\mathrm{PTT}_{\text {Pukan }} * *$ & $124,0 \mathrm{a}$ & 192 a & $18,0 \mathrm{a}$ & $11,0 \mathrm{a}$ \\
\hline PTT $_{\text {Exist }} * *$ & 113,0 bc & $167 \mathrm{c}$ & $14,0 \quad \mathrm{c}$ & $8,0 \quad c$ \\
\hline Nilai Tengah (U) & 117,0 & 185,7 & 16,0 & 9,7 \\
\hline $\mathrm{KK}(\%)$ & 8.6 & 8,9 & 14,8 & 16,5 \\
\hline
\end{tabular}




\subsection{Komponen hasil dan hasil}

Penerapan PTTPukan padi ramah lingkungan meningkatkan jumlah gabah isi per malai secara nyata dibandingkan dengan perlakuan PTT $_{\text {Petro maupun }}$ PTT $_{\text {Eksist }}$ (Tabel 4). Peningkatan jumlah gabah isi per malai sebesar $27,94 \%(217,0-182,5) / 182,5 \times 100 \%$

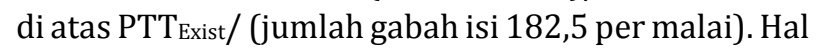
ini didukung oleh jumlah anakan produktif pada perlakuan 2 t Pukan/ha ( PTT $_{\text {Pukan }}$ ) paling tinggi (Tabel 3). Semakin tinggi jumlah anakan produktif menunjukkan jumlah malai tiap rumpun semakin tinggi pula. Sedangkan perlakuan PTTPetro meningkatkan jumlah gabah isi per malai sebesar 19 $\%$ di atas PTTExist (jumlah gabah isi per malai $=182,5$ ).

Perlakuan PTTPukan meningkatkan berat 1000 biji secara nyata dibandingkan dengan $\mathrm{PTT}_{\text {Exist}} /$ kontrol (Tabel 4). Peningkatan berat 1000 biji sebesar $6,84 \%(29,75-28,5) / 28,5 \times 100 \%$ di atas PTT $_{\text {Exist }}$ atau kontrol (Berat $1000 \mathrm{biji}=28,5 \mathrm{~g}$ ). Hal ini diduga karena perlakuan PTTPukan mampu memperbaiki sifat kimia tanah seperti ketersediaan unsur hara $\mathrm{P}$, meningkatkan daya jerap tanah terhadap anion-anion sehingga proses pengisian biji lebih sempurna. Karena unsur $P$ diperlukan untuk pembentukan dan kebernasan biji. Sedang perlakuan PTTPetro meningkatkan jumlah berat 100 biji sebesar $4,40 \%$ di atas PTT $_{\text {Exist }}$ (jumlah gabah isi per malai : 182,5). Bila dibandingkan dengan Pupuk kandang kenaikkan berat 1000 biji lebih rendah hal ini diduga karena bentuk petroganik granula sehingga ketersediaan unsur hara yang telarut lebih lambat.

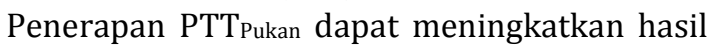
padi Rojolele secara nyata dibandingkan dengan PTT $_{\text {Exist/ kontrol (Tabel 4). Peningkatan hasil pada }}$ perlakuan ini sebesar $48,6 \%$ di atas $\mathrm{PTT}_{\text {Exis }} /$ kontrol (hasil 3,620 t Gkg/ha). Hal ini didukung oleh jumlah anakan produktif (Tabel 3) dan komponen hasil pada perlakuan 2 t Pukan/ha paling tinggi (Tabel 3). Semakin tinggi jumlah jumlah gabah isi per malai dan berat 1000 biji menunjukkan hasil padi yang diperoleh semakin tinggi pula. Sedangkan perlakuan dengan menerapkan PTTPetro meningkatkan jumlah gabah isi per malai sebesar $30 \%$ di atas PTT $_{\text {Exist }}$ /kontrol(hasil: 3,620 t Gkg/ha).

Tabel 4. Penerapan Pengelolaan tanaman terpadu terhadap komponen hasil dan hasil padi var. Rojolele dilahan sawah irigasi di Desa Gempol, Karanganom, Klaten MK 2016

\begin{tabular}{lccc}
\hline \multicolumn{1}{c}{ Perlakuan } & Jml gabah isi/malai & Berat 1000 biji (g) & Hasil (t gkp/ha) \\
\hline PTT-Petro** $^{*}$ & $217,0 \mathrm{~b}^{*}$ & $29,75 \mathrm{ab}^{*}$ & $4,735 \mathrm{ab}$ \\
PTT-Pukan** $^{*}$ & $233,5 \mathrm{a}$ & $30,45 \mathrm{a}$ & $5.390 \mathrm{a}$ \\
PTT Exist $_{\text {Nilai tengah (U) }}^{182,5 \mathrm{c}}$ & $28,50 \mathrm{c}$ & $3.620 \mathrm{c}$ \\
KK (\%) & 212,00 & 29,60 & 4.680 \\
\hline
\end{tabular}

*) Angka sekelom diikuti huruf sama tidak berbeda menurut $U B D, 05$.

**) PTT Petr $_{\text {: }}(100$ Urea +100 ZA+ 250 Phonska+ 500 Petroganik) kg/ha. **) PTT Pukan: $(0,1$ Urea+ 0,1 ZA+ 0,250

Phonka +2 Pukan) t/ha; PTT Exist:(0,150 Urea + 0,2 Pukan)t/ha

\subsection{Emisi Gas Rumah Kaca (GRK)}

Perlakuan PTT Petro Padi ramah lingkungan dapat menurunkan total emisi gas methan paling tinggi yaitu 33,29 \% (50,73-76,05)/76.05 x 100\% di bawah $\mathrm{PTT}_{\text {Exist }} / \mathrm{kontrol}$ (total emisi 76,05 $\mathrm{kg} \mathrm{CH}_{4} / \mathrm{ha}$ /musim) seperti disajikan pada Tabel 5. Sedangkan penerapan

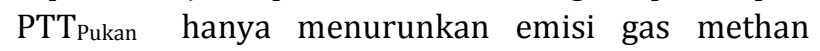
sebesar 13,62\% (50,73 - 65,63)/50,73x 100\% dibawah kontrol (total emisi 76,05 kg $\mathrm{CH}_{4} / \mathrm{ha}$ /musim). Hal ini diduga karena salah satu komponen teknologi PTT Padi adalah penggunaan $\mathrm{N}$ dengan sumber ZA. Seperti hasil penelitian yang di laporkan oleh Kartikawati dkk., 2011, bahwa penambahan ZA sebesar $100 \mathrm{Kg} / \mathrm{ha}$ juga menghasilkan emisi $\mathrm{CH}_{4}$ yang rendah. Hal ini disebabkan karena ion sulfat $\left(\mathrm{SO}_{4}\right)$ yang merupakan hasil samping hidrolisis ZA dapat memperlambat penurunan redoks tanah dan sulfur dalam pupuk merupakan salah satu penghambat perkembangan bakteri metanogeneis. Cara lain untuk menekani emisi $\mathrm{CH}_{4}$ adalah aplikasi pupuk $\mathrm{N}$ dibenamkan, karena mengurangi hilangnya $\mathrm{N}$ karena volatilisasi).
Kemampuan tanaman padi melepaskan gas $\mathrm{CH}_{4}$ berbeda-beda, tergantung karakteristik padi. Setiap varietas memiliki sifat dan aktivitas akar yang berbeda, seperti besar eksudat akar dan kecepatan pertukaran gas yang erat kaitannya dengan volume gas $\mathrm{CH}_{4}$.Eksudat atau hasil autoksis akar padi merupakan sumber karbon bagi bakteri methanogenik penghasil $\mathrm{CH}_{4}$. Bakteri pembentuk $\mathrm{CH}_{4}$ dapat berkembang baik pada kondisi tergenang, dimana $\mathrm{Eh}<-150$ dan pH 6 - 8 dengan suhu tanah 25 - $35{ }^{\circ} \mathrm{C}$ (Wihardjaka et al., 1999).

Setyanto (2013) menyatakan bahwa hasil inventarisasi emisi gas metana di beberapa sentra produksi di Jawa Tengah bervariasi. Variasi ini tidak hanya dipengaruhi secara signifikan oleh jenis tanah tetapi juga dipengaruhi oleh cara pengelolaan tanah dan tanaman. Emisi gas metana dapat ditekan antara lain dengan pemilihan varietas, penggunaan pupuk anorganik, pengaturan air irigasi dan pemakaian herbisida. 
Tabel 5. Penerapan PTT Padi lokal potensial (var. Rojolele) terhadap emisi gas methan pada lahan sawah irigasi di Gempol, Kec. Karanganom,Klaten MK 2016

\begin{tabular}{lcccc}
\hline \multirow{2}{*}{ Perlakuan } & \multicolumn{4}{c}{ Rerata Fluks $\left(\mathrm{mg} \mathrm{CH} / \mathrm{m}^{2} /\right.$ hari) pada umur } \\
\cline { 2 - 5 } & $42 \mathrm{Hst}$ & $63 \mathrm{Hst}$ & $105 \mathrm{Hst}$ & $112 \mathrm{Hst}$ \\
\hline PTT-Petro* & 56,85 & 43,32 & 17,81 & 6,53 \\
PTT-Pukan* & 46,86 & 184,79 & 11,95 & 4,65 \\
PTT-Exist* & 106,99 & 85,96 & 13,25 & 5,73 \\
\hline
\end{tabular}

*) PTTPetr : (100 Urea +100 ZA+250 Phonska+ 500 Petroganik) $\left.\mathrm{kg} / \mathrm{ha}^{* *}\right)$ PTTPukan: $(0,1$ Urea+ 0,1 ZA+ 0,250

Phonka +2 Pukan) t/ha; PTT Exist:(0,150 Urea + 0,2 Pukan)t/ha. Hst - Hari setelah tanam.

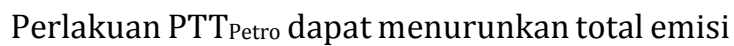
gas $\mathrm{N}_{2} \mathrm{O}$ tertinggi sebesar $9,61 \%$ di bawah perlakuan $\mathrm{PTT}_{\text {Exist }}$ /kontrol (total emisi 2,08 $\mathrm{kg} \mathrm{N}_{2} \mathrm{O} / \mathrm{ha}$ /musim) seperti disajikan pada Tabel 6. Hal ini diduga karena penggunaan pupuk $\mathrm{N}$ yang bersumber dari ZA dapat dan mempertahankan kondisi reduktif dapat menurunkan emisi gas $\mathrm{N}_{2} \mathrm{O}$ dari tanah. Sesuai dengan pendapat Kartikawati $d k k$,(2011) bahwa pemberian bahan penghambat nitrifikasi dapat mempertahankan unsur $\mathrm{N}$ bentuk senyawa $\mathrm{NH}_{4}^{+}$, sehingga dapat menurunkan emisi gas $\mathrm{N}_{2} \mathrm{O}$ dari tanah sawah. Hal ini sejalan pula dengan hasil penelitian Tusan (2009) di Balai Lingkungan Pertanian (Balingtan), Jakenan menunjukkan bahwa dari berbagai sistem pengelolaan padi sawah terhadap dinamika sifat kimia tanah dan gas metana menunjukkan bahwa Total emisi gas $\mathrm{CH}_{4}$ tertinggi dihasilkan pada perlakuan Non-PTT tergenang yaitu sebesar 436.66 $\mathrm{kg} / \mathrm{ha} /$ musim dan terendah pada perlakuan SRI Intermittent yaitu sebesar $145.55 \mathrm{~kg} / \mathrm{ha} /$ musim, total emisi tertinggi dari perlakuan yang diterapkan adalah Non-PTT Tergenang;

Perlakuan PTT Pukan $_{\text {sebagai salah satu komponen }}$ dalam Pengelolaan tanaman (PT) Padi ramah lingkungan justru menunjukkan total emisi gas $\mathrm{N}_{2} \mathrm{O}$ paling tinggi yaitu 2,84 $\mathrm{kg} \mathrm{N}_{2} \mathrm{O} / \mathrm{ha} /$ musim atau meningkat $36,5 \%$ di bawah pengelolaan tanaman menurut petani/kontrol (total emisi 2,08 kg $\mathrm{N}_{2} \mathrm{O} /$ ha/musim) seperti disajikan pada Tabel 6. Hal ini diduga karena pupuk kandang dalam kondisi reduktif akan melepaskan gas $\mathrm{NH}_{3}$ dan bila pengairan berselang saat air kering (kondisi oksidatif) gas amoniak akan tereduksi sebentar dan menjadi teroksidasi sehingga memacu proses nitrifikasi sehingga meningkatkan emisi gas $\mathrm{N}_{2} \mathrm{O}$ dari tanah.

Tabel 6. Penerapan pengelolaan tanaman terpadu padi varietas Rojolele terhadap emisi gas emisi gas $\mathrm{N}_{2} \mathrm{O}$ pada lahan irigasi di Gempol, Karanganom, Klaten MK 2016

\begin{tabular}{lcccc}
\hline \multirow{2}{*}{ Perlakuan } & \multicolumn{4}{c}{ Emisi } \\
\cline { 2 - 5 } & $42 \mathrm{HST}$ & $63 \mathrm{HST}$ & $105 \mathrm{HST}$ & $112 \mathrm{HST}$ \\
\hline PTT-Petro* $^{*}$ & 681,87 & 3945,90 & 716,91 & 433,02 \\
PTT-Pukan* $_{\text {PTT }_{\text {Exist* }}}$ & 704,37 & 6698,60 & 1132,14 & 191,87 \\
\hline
\end{tabular}

\section{Kesimpulan}

1 Penerapan Pengelolaan tanaman terpadu Padi ramah lingkungan (PT-Pukan) dengan komponen teknologi (benih var. Rojolele, tanaman bibit umur 20 hari, cara tanam jajar legowo tipe 2:1 dengan penerapan pemupukan berdasarkan Perangkat Uji Tanah Sawah (PUTS) sumber N $(Z A+$ Phonska $)+2$ t Pukan/ha, diikuti aplikasi pestisida nabati dan penerapan irigasi berselang (intermitent irrigation) memberikan hasil tertinggi (5,219 t Gkp/ha) meningkatkan hasil 30

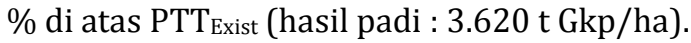

2 Penerapan PTTPukan Padi ramah lingkungan menurunkan emisi gas methan sebesar 13,62\% dibawah kontrol (total emisi 76,05 kg $\mathrm{CH}_{4} / \mathrm{ha} / \mathrm{musim}$ ) , namun belum mampu menurunkan emisi gasi $\mathrm{N}_{2} \mathrm{O}$ dengan emisi gas $\mathrm{N}_{2} \mathrm{O}$ sebesar (emisi : 2,84 $\mathrm{kg} \mathrm{N}_{2} \mathrm{O} / \mathrm{ha} /$ musim).

\section{Daftar Pustaka}

Ahyar, M., Aziz N.B., dan Widada. 2012. Perilaku Bertani Padi Sawah Yang Mitigatif Terhadap Perubahan Iklim di Kabupaten Bima. Prosiding Seminar
Nasional Pengelolaan Sumberdaya Alam dan Lingkungan. Semarang, 11 Sept 2012.

Ariani, M., R. Kartikawati, dan P. Setyanto. 2011. Emisi Nitro Oksida (N20) pada Sitem Pengelolaan Tanaman di Lahan Sawah Tadah Hujan. Jurnal Tanah dan Iklim No. 34/2011.

Badan Litbang Pertanian. 2007. Petunjuk Teknis Lapang: PTT padi sawah irigasi. Badan Litbang Pertanian. Jakarta. $40 \mathrm{p}$

Badan Perencana Pembangunan Nasional, 2010.Indonesia Climate Change Sektoral Roadmap : Sektor Pertanian. Jakarta. 94 hal.

Departemen Pertanian, 2007. Agenda Nasional 2008-2015, Rencana Aksi Pengurangan Emisi Gas Rumah Kaca Sektor Pertanian. Jakarta. 23 hal.

Fauziah Harahap, 2012. Fisiologi Tumbuhan. Universitas Medan. Press. 148 Halaman.

Isminingsih, 2009.Studi Kecenderungan Emisi Gas Rumah Kaca (GRK) Dan Neraca Karbon pada Berbagai Sistem Pengelolaan Tanaman Padi.Skripsi. Departemen Teknik Pertanian. Fakultas Teknologi Pertanian. Institut Pertanian Bogor.

Kartikawati, R,. H.L. Susilowati, M. Ariani dan P. Setyanto, 2011. Teknologi Mitigasi Gas Rumah Kaca (GRK) dari Lahan Sawah. Agroinovasi Nomor 3423 : 2011. Badan Litbang Pertanian, Departemen Pertanian. Jakarta. Hal 7 -12. 
Kementerian Negara Lingkungan Hidup Republik Indonesia, 2007.Rencana Aksi Nasional dalam Menghadapi Perubahan Iklim. Jakarta. 103 hal.

Kementerian Negara Lingkungan Hidup dan Kehutanan Republik Indonesia, 2017. Laporan Inventarisasi Gas Rumah Kaca (GRK) dan MRV. 75 Halaman.

Kushartanti, E., T. Suhendrata, S. Bahri, 2010. Laporan hasil Pendampingan PTT padi, Jagung, Kedelai dan Kacang Tanah di Jawa Tengah. Balai Pengkajian Teknologi Pertanian. Jawa Tengah.

Marschner, H., 1986. Mineral Nutrition of Hogher Plants. Acc Press. Harcourt Jovanovich Publishers.London, San Diego, New York, Berkeley, Boston, Sydney, Tokyo, Toronto.673 Halaman.

Pusat PVTPP, 2011. BERITA RESMI PVT Pendaftaran Varietas Lokal. Padi Mentik WangiSusu.Online:http://ppvt.setjen.pertanian.g o.id/ppvtpp/files/Padi\%20Mentikwangi $\% 20$ susu .pdf. Diakses tanggal 22 April 2013.

Pusat PVTPP, $2013 . \quad$ Online :http://ppvt.setjen.pertanian.go.id/ppvtpp/berita -498-optimalisasi-pemanfaatan--varietas-unggulpropinsi-jawa-tengah.html Diakses tgl 23 April 2013.

Pusat Penelitian Tanah, 1986. Petunjuk teknis analisis tanah dan kriteria status unsur hara tanah. Pusat Penelitian Tanah Bogor, 45 Halaman.

Sarlan, A. 2011. Peran Pendekatan Teknologi dan InputProduksi Terhadap Hasil Padi. Penelitian Pertanian.Bogor Volume 20: $(6-12)$.
Setyanto, P 2006. Varietas Padi Rendah Emisi Gas Rumah Kaca. Warta Penelitian dan Pengembangan Pertanian. Vol. 28, No. 4. 2006.

Setyanto, P. dan R. Kartikawati, 2008.Sistem Pengelolaan Tanaman Padi Rendah Emisi Gas Methan.Jurnal Pene. Pertanian Tan. Pangan. 27 (3) : 162 - 171.

Setyanto, P. 2013. Mitigasi gas metan dari lahan sawah.Online http://balittanah.litbang.deptan.go.id/dokumenta si/buku/tanahsawah/tanahsawah10.pdf.Diakses tanggal 22 April 2013.

Sumarno, I.G. Ismail, dan S. Partohardjono. 2000. Konsep usahatani ramah lingkungan. Dalam : Makarim et al (eds). Simposium Penelitian Tanaman Pangan IV. Pusat Penelitian dan Pengembangan Tanaman Pangan. Bogor.

Tusan, I.P. 2009. Pengaruh Berbagai Sistem Pengelolaan Padi Sawah terhadap Dinamika Sifat Kimia Tanah Dan Gas Metana $\left(\mathrm{CH}_{4}\right)$.Skripsi. Departemen Teknik Pertanian. Fakultas Teknologi Pertanian. Institut Pertanian Bogor.

Wihardjaka, A., P. Setyanto dan A.K Makarim, 1999. Pengaruh Penggunaan Bahan Organik terhadap Hasil Padi dan Emisi Gas Methan pada Lahan Sawah. Dalam: Partohardjono, S dkk. (Eds). Risalah Seminar Hasil Penelitian Emisi Gas Rumah Kaca dan Peningkatan produktivitas Padi di Lahan Sawah. Bogor, 24 April 1999. Puslitbangtan Bogor p : $44-53$. 